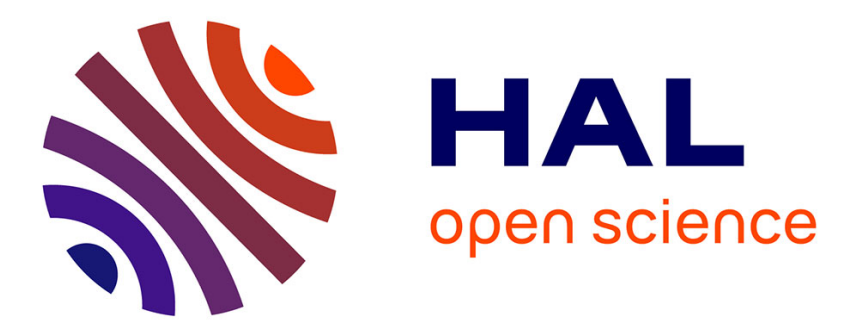

\title{
Interaction between Surface and Subsurface Flows: Somme Basin
}

Dominique Thiéry

\section{To cite this version:}

Dominique Thiéry. Interaction between Surface and Subsurface Flows: Somme Basin. Tanguy J.M. Practical Applications in Engineering (Volume 4), Wiley/ISTE London, pp.143-156, 2010, Environmental Hydraulics, 10.1002/9781118557792.ch13 . hal-01061788

\section{HAL Id: hal-01061788 https://hal-brgm.archives-ouvertes.fr/hal-01061788}

Submitted on 8 Sep 2014

HAL is a multi-disciplinary open access archive for the deposit and dissemination of scientific research documents, whether they are published or not. The documents may come from teaching and research institutions in France or abroad, or from public or private research centers.
L'archive ouverte pluridisciplinaire HAL, est destinée au dépôt et à la diffusion de documents scientifiques de niveau recherche, publiés ou non, émanant des établissements d'enseignement et de recherche français ou étrangers, des laboratoires publics ou privés. 


\section{Interaction between Surface and Subsurface Flows: Somme Basin}

The aim of this application example is to demonstrate the advantage of using a coupled model: hydroclimatic assessment - surface flow - subsurface flow to represent the flows in a large river basin that is linked up to subsurface groundwater.

\subsection{Problematic issue}

In France, major flooding of the Somme occurred during Winter 2000 and spring 2001, with several hundred communes subjected to damage (see figure 13.1). The floods occurred over a long period, mainly during March and April 2001, due to it unusually being triggered by a groundwater overflow rather than surface runoff, which explains their residence time of several weeks. With an aim to assessing the risk and anticipating the occurrence of other floods, it was necessary on the one hand to analyze the operation of the river basin and the mechanisms that trigger flooding of this type, and, on the other hand, to develop an operational forecast model. The general procedure that is implemented within the framework of the BRGM's public service actions in collaboration with the Picardie region's environmental department (DIREN) and Météo France for the data are described in detail, together with the main results obtained by Amraoui et al. [AMR 02, ARM 03].

This application shows how a spatialized subsurface hydrodynamics model, coupled with a hydroclimatic assessment module, enabled the behavior of the basin to be reproduced across its full extent and contributed to an understanding of the mechanisms at the origin of floods of this type. It also demonstrates how a lumped hydrological model, which is much simpler but adapted to forecasting, enabled operational forecasts to be produced in 2002 and 2003 for the flow rate of the Somme at Abbeville.

The flood in a few figures:

- 1,100 people evacuated,

- 108 communes affected,

- floods lasting over 2 months,

- 150 million Euros' worth of damage.

\subsection{The Somme river basin}

The Somme basin located to the North of the Parisian basin (France) occupies a surface area of around 7,400 km2 (Eigure 13.2). The basin's main aquifer is composed of Senonian and upper Turonian permeable chalk. This aquifer is covered with quaternary alluviums in the somme valley and in some of the valleys of its tributaries. The plateaus are covered with silt. The cracked, permeable chalk is around 50 meters' thick. It is at the origin of the most significant flows. It is drained both in low water and high water periods, by the drainage system made up of the somme and its main tributaries, the Avre, the Selle, the Hallue and the Ancre.

There is a large amount of data available on this basin: 54 piezometric time series, five river flow rate time series, 12 rain gauge stations (Figure 13.3).

\subsection{Modeling methodology}


Two approaches have been used - to understand the mechanisms at the origin of the spring 2001 flood in the somme basin and to evaluate the possibilities for developments enabling a reduction in the frequency of flooding in the basin, a fine-tuned spatialized modeling was created with a physical representation of the piezometric levels on all points of the basin and the flow rates in all sections of the watercourses;

- in order to forecast the risk in the mid-term (one to three months) of the flow rate in the river exceeding the critical level a much more lightweight adaptative lumped hydrological model enables operational flow-rate forecasts in the Somme at Abbeville.

In fact, these two modelings are complementary as the lumped hydrological model was also used to compute the hydrological assessment at each area of the spatialized model.

\subsection{The modeling tools used}

\subsubsection{The spatialized model}

The spatialized modeling makes use of a meshed model that enables a deterministic simulation of the majority of the phenomena occurring on the basin: the BRGM's MARTHE code [THI 93]. This model incorporates (see figure $13.4)$

- the hydroclimatic assessment in the first few meters of soil (rain, evapotranspiration);

- the surface flows towards the drainage system;

- infiltration towards the groundwater;

- flows in the subsurface groundwater;

- the groundwater overflow;

- the flows within the drainage system;

- the interactions between the groundwater and the drainage system.

This distributed model takes account of the geometry of the aquifer system and the spatial variability of its hydrodynamic properties. The hydroclimatic assessment is calculated in the different areas by integrating the spatial variability of the precipitation (and the soil parameters). The spatialized modeling thus enables us to understand the operation of the aquifer system and simulate the piezometric levels and flow rates in the rivers. It may be used to analyze development scenarios for reducing flooding risks.

The GARDENIA reservoir model is used [ROC 84, THI 03). Using the average time series of rainfall and potential evapotranspiration (PET) on the river basin, it enables a simulation of the changes in flow rate at the basin outlet, and of changes in the piezometric level at one point of the basin.

Figure 13.5 presents the operating diagram of the model. In its simplest, most widely used version, the model is composed of three reservoirs stacked one on top of the other. Taking them from top to bottom, we can differentiate the following: 
- the surface reservoir, U. At each timestep it receives, as a forcing, a homogeneous value of precipitation and potential evapotranspiration. It possesses a retention capacity (the reserve available for evapotranspiration) that represents both the interception by the vegetation and the soil's capacity effect. This capacity must be entirely saturated before it can produce a surplus (effective rain) towards reservoir $\mathrm{H}$, which will generate surface run-off towards the watercourse and infiltration;

- intermediate reservoir $\mathrm{H}$ is fed by the draining of reservoir U. Globally, it represents the non-saturated area. Its role is partly to carry out the nonlinear sharing between the surface run-off towards the watercourse and the groundwater recharge, and partly to reproduce the delay between an infiltration and the corresponding groundwater recharge;

- subsurface reservoir Gl is fed by the draining of reservoir H in the form of a recharge. This reservoir is characterized by a depletion time, which globally represents the operation of the subsurface groundwater.

The parameters of this model lumped (soil retention capacity, depletion time, sharing between surface run-off and infiltration) are very low in number. As they are lumped, they are not accessible for measurements and need to be calibrated in order to best reproduce the measured flow rates. The calibration will therefore be all the more robust the longer the flow rate observation period, and the wider the variation range presented by the observed flow rates.

\subsubsection{Meshing of the coupled model and limit conditions}

The modeled domain covers the entire Somme basin (the Upper Somme and the Lower Somme), the Southwestern half of the Authie basin to the North and the Northeastern half of the Bresle basin to the Southwest. It is delimited by the Authie valley and the heights of the Cambrésis to the North, le Vermandois to the East, the Noyonnais hills to the Southeast, the Bresle valley to the Southwest, and the English Channel to the West.

The model was built according to a finite volumes scheme. The study area, covering an area of $7,397 \mathrm{~km}^{2}$, is discretized as a plane made up of square meshes with sides measuring 500 meters. The wet valley of the Somme is refined using three partial mesh nests with sides measuring 100 meters (Figure 13.6). The chalk groundwater is modeled as a single layer, taking into account the interactions between the groundwater and the rivers that cross the basin. In the modeled layer, the meshes, which number more than 66,000, are parallelepipedshaped. Their upper face corresponds to the layer's top (in this case, the topography), whilst their lower face corresponds substratum of the formation. The Senonian chalk groundwater is assumed to be in hydraulic continuity with the alluvial groundwater. The aquifer's geometry was determined based on a large number of drillings. The drainage system is represented by 4,560 river meshes (Figure 13.7):

- 5,987 drilling points used in order to define the Chalk formation top;

- 1,350 points used in order to define the Turonian formations;

- 864 cross-sections which specify the hardened levels in the Senonian Chalk.

The boundary conditions introduced into the subsurface model represent three types:

- with prescribed hydraulic head along the Authie and the Bresle as far as the confluence with the Liger, with a hydraulic head equal to zero on the English 
Channel side (the Western limit of the model). Outside of these limits, conditions with prescribed hydraulic head were applied to the following rivers: the Maye, Rivière des Iles, the Vimeuse and the Liger, all of which are rivers that are not connected to the Somme;

- with zero flow on the side limits at all other locations;

- with groundwater-river exchange conditions. This condition concerns both the Somme and its tributaries.

\subsubsection{Calibration period for the coupled model and modeling timestep}

The calibration of the model's parameters (permeabilities, storage coefficients, soil retention capacity, groundwater percolation time, clogging of the embankments, etc.) was performed for the period 1989-2003. The model's validation was performed for the period 2004-2006.

Across the entire period 1989-2006, the computing timestep was as follows:

- daily for the hydroclimatic assessments (evaporation, infiltration, surface run-off, etc.);

- weekly for the subsurface flows, which are significantly slower.

\subsubsection{Results obtained following calibration of the coupled model}

Following the calibration, the simulation of the piezometric levels of around 40 piezeometers is entirely satisfactory. The flow rates measured on the somme at Abbeville, and its sub-basins are correctly simulated, with the exception of those of Nièvre's sub-basin. Figures 13.8 and 13.9 illustrate the quality of the calibration, including during the validation period.

The analysis of the results produced by the coupled model enabled the groundwater's contribution to the total flow rate of the somme to be determined. Figure 13.10 shows that in low water periods, virtually the entire flow rate of the Somme comes from the contribution of the groundwater (the sum of the overflow and groundwater river exchanges in the somme and its tributaries). During flood periods, such as spring 2001, the contribution of the groundwater is continually greater than $80 \%$. According to the model, the overflow flow rates represent an average of around 35\% of the total flow rate, and the groundwater river exchanges represent around $60 \%$

The modeling also highlighted that the 2000-2001 flood was caused by three successive wet years, and exceptional rainfall in 2000-2001, which resulted in the following:

- a significant increase in the groundwater recharge and therefore an increase in the water stock within the chalk groundwater;

- an overflow of the groundwater and a significant increase in the exchange flow rates between the groundwater and the watercourse.

In certain sub-basins, such as that of the Hallue, the unsaturated, cracked area of the chalk also had an important role to play in triggering the flood. In effect, at high saturation, the cracks became highly conductive and very rapidly led the rain surplus down to the groundwater. 


\subsection{Lumped hydrological modeling for real-time forecasts}

The GARDENIA model, described above, was applied at the daily timestep to the flow rates of the Somme at Abbeville, based on an average rainfall on the basin, but results that were virtually as good were obtained from the rainfall at the Glisy rain gauge station alone. The parameters were calibrated based on the nine years making up the period 1995-2003. However, given the inertia of the system, the computations were launched seven years beforehand in order initialize the model.

In contrast to the spatialized model, the characteristics of the lumped hydrological model are as follows:

- requiring very little computation time, it operates at the daily timestep and uses a long start up period;

- involving very few parameters, it is able to use a highly effective automatic calibration method.

After calibration, the lumped hydrological model may be used in forecasting mode. In this mode, the model uses self-adaptive methods for readjusting the levels of its reservoirs before the forecast date, so as to minimize the simulation deviations on the date the forecast is issued.

The input data making up the forcing (precipitation and PET) are known up until the forecast issue date. As of course the precipitation cannot be forecast over a duration of more than a few days, the flow rate forecast will be produced in probabilistic form. For the duration of the forecast, the model will be successively fed with the precipitation observed during the same period over previous years.

In practice, on the Somme basin, there is daily rain gauge available that covers a period of 41 years at a station near Amiens. The model thus performs 41 successive simulations during the forecast period (e.g. 60 days) based on the condition of the reservoirs on the day the forecast is issued. The 41 simulations for 60 days are then analyzed, and for each day, we determine those flow rates with a given probability of non-exceedance. We can thus deduce the flow rate envelope representing this probability of non-exceedance. We can also compute the risk of, in the coming month(s), exceeding a flow rate threshold (83 $\mathrm{m} 3 / \mathrm{s}$ for the somme) corresponding to an overflow of the main channel.

\subsection{Results and discussion}

Two modeling approaches were applied on the Somme basin.

Spatialized modeling enabled the reproduction of the piezometric levels across the whole basin, as well as the flow rates in the different watercourses. This type of modeling is very powerful, both in enabling an understanding of phenomena generating floods, and for its ability to forecast changes in level and flow rates resulting from rainfall or development scenarios. The problems encountered in the Somme basin are linked to the overflow of the main channel, however, and require an accurate computation of the water lines that takes account of the complex geometry of the structures (canals, sluice gates, etc.), and this is beyond the scope of this model. The results produced by the MARTHE code at all points (groundwater overflow rates, surface run-offs towards the watercourses, groundwater/river exchanges, etc.) may, however, be introduced into a flood propagation model. A propagation computation of this kind using the results of the spatialized model was performed by the SOGREAH with the CARIMA computer code (Figure 13.13). 
The results obtained were very satisfactory because they enabled the flow rates at certain outlets of the river basin to be established, as well as certain measured flood tide marks. They also enabled the study of scenarios for developing the basin in order to limit the effects of future floods.

The lumped hydrological modeling, much simpler but with much more limited objectives, allowed an operational model to be developed for forecasting the flow rates of the Somme in Abbeville. This model was in regular operation, roughly every two weeks, over the course of the winter of 2001-2002 and 20032004. The benefit of a forecast model of this kind is the high accuracy of the computed flow rates, the implementation speed, the use of a limited amount of available data very rapidly, and the ability to generate scenarios graduated in terms of probability.

\subsection{Bibliography}

[AMR 02] AMRAOUI N. N., GOLAZ C., MARDHEL V., NEGREL P., PETIT V., PINAULT J. L. and POINTET T., Simulation avec modèles des hautes eaux de la Somme, BRGM Report $\mathrm{RP}-51827-\mathrm{FR}, 2002$.

[AMR 03] AMRAOUI N., GOLAZ C., MARDHEL V. and PINAULT J. L., "Evaluation du risque d'inondation dans le bassin de la Somme: Apport de l'approche globale et de l'approche distribuée", 3rd SIRNAT Conference, Orléans, 2003

[ROC 84] ROCHE P. A. and THIERY D., Simulation globale de bassins hydrologiques. Introduction à la modélisation et description du modèle GARDENIA, BRGM Report 84 SGN 337 EAU, 1984 .

[THI 93] THIÉRY D., "Modélisation des aquifères complexes - Prise en compte de la zone non saturée et de la salinité. Calcul des intervalles de confiance", Revue Hydrogéologie, no. 4, pp.325-336, 1993.

[THI 03] THIERY D., Logiciel GARDENIA version 6.0, User's guide, BRGM Report no. $\operatorname{RP} 52832,2003$. 